\section{(2)}

\section{Psychology \& Neuroscience}

ISSN: 1984-3054

landeira@puc-rio.br

Pontifícia Universidade Católica do Rio de Janeiro

Brasil

Solovieva, Yulia; Lázaro, Emelia; Rosas, Yolanda; Quintanar, Luis; Escotto, Alejandro; Sánchez, Jose

Gabriel

Mathematics acquisition in Mexico: Research on teaching, acquisition difficulties, and correction

Psychology \& Neuroscience, vol. 7, núm. 4, 2014, pp. 481-491

Pontifícia Universidade Católica do Rio de Janeiro

Rio de Janeiro, Brasil

Available in: http://www.redalyc.org/articulo.oa?id=207032913007 


\title{
Mathematics acquisition in Mexico: Research on teaching, acquisition difficulties, and correction
}

\author{
Yulia Solovieva ${ }^{1}$, Emelia Lázaro $^{1}$, Yolanda Rosas ${ }^{2}$, Luis Quintanar ${ }^{1}$, Alejandro Escotto $^{3}$, and Jose \\ Gabriel Sánchez ${ }^{3}$ \\ 1- Benemérita Universidad Autónoma de Puebla, Puebla, Mexico \\ 2- Instituto de Neuropsicología y Piscopedagogía para la Intervención y Profesionalización Yollixmatiliztli S.C., Ciudad de \\ México, Mexico \\ 3- National Autonomous University of Mexico, Ciudad de México, Mexico
}

\begin{abstract}
The present article presents the current data on the methods of assessing, correcting, and teaching mathematics at the preschool and school levels in Mexico. The authors seek to present objective information from the perspectives of traditional and experimental pedagogy and cognitive and historical cultural neuropsychology, which are the most popular perspectives among teachers, psychologists, and researchers in Mexico. Testing is presented according to cognitive neuropsychology and historical cultural paradigms. Differentiating between traditional pedagogical and neuropsychological points of view with regard to learning processes and teaching mathematics is also discussed. The reasons for frequent difficulties in learning mathematics are presented and argued from a cognitive perspective and using an Activity Theory approach. The authors attempt to describe the real situation and determine different ways of overcoming the difficulties at the preschool and school levels. Ways of preventing possible difficulties are also discussed, including symbolic, logical, spatial, and numerical components and their interactions. Some research on the Activity Theory concept of the teaching-learning process and a gradual introduction of scientific concepts at school age are presented. The results showed that children acquired significant symbolic abilities that are necessary to understand the concept of the decimal system. We consider that this article may aid our understanding of the origin of mathematics difficulties and the necessity of constantly collaborating and exchanging psychological, pedagogical, and neuropsychological ideas. Keywords: mathematics in Mexico, assessment of mathematics, prevention and correction of difficulties, school age, mathematics teaching.
\end{abstract}

Received 30 October 2013; received in revised form 19 September 2014; accepted 28 October 2014. Available online 16 December 2014.

\section{Introduction}

In Mexico, as in many other countries, children's level of knowledge in mathematics is considerably low. The official statistics presented by the Secretary of Public Education (SEP, 2013) in Mexico were based on the National Assessment of Academic Achievement in Schools (ENLACE), which began in 2006. This program of assessing academic level was developed to generate a single scale of national characteristics to provide comparable information on the knowledge and skills that students have in the assessed areas, including

Yulia Solovieva, Emelia Lázaro, and Luis Quintanar, Autonomous University of Puebla, Faculty of Psychology, Master in neuropsychological diagnosis and rehabilitation, México, Puebla. Yolanda Rosas, Instituto de Neuropsicología y Piscopedagogía para la Intervención y Profesionalización Yollixmatiliztli S.C.. Alejandro Escotto and Jose Gabriel Sánchez, Department of Psychology of Faculty of Superior Studies Zaragoza, Autonomous University of Mexico City. Correspondence regarding this article should be directed to: Yulia Solovieva, email: yulia.solovieva@correo.buap.mx mathematics. The test is applied each year in public and private schools in the country. Children from the 3rd to 6th grades of elementary school and students from the 1 st to 3 rd years of secondary school are included in the testing according to the plans and programs of formal studies in each subject area. In high school, the test is applied for students who are currently enrolled in the last grade of high school and assesses basic disciplinary competence in the fields of Communication (reading comprehension) and Mathematics.

The parameters of assessment are the following: (a) Insufficient (requires more knowledge and the development of skills in the assessed subject), (b) Elementary (requires strengthening the majority of knowledge and the development of skills in the assessed subject, (c) Good (shows appropriate domain knowledge and possess skills in the assessed subject), and (d) Excellent (has a high level of knowledge and skills in the assessed subject).

Historical results in the area of basic mathematics have shown that $82.4 \%$ of the children had "insufficient" 
and "elementary" levels (i.e., the lowest levels of performance) during the first assessment in 2006. Although this percentage has decreased annually since then, $51.2 \%$ of students remained at these levels in 2013, and $48.8 \%$ of students were "good" or "excellent." The situation is even worse in high school. In 2013, 78.1\% of the students were at "insufficient" or "elementary" levels, and only $21.9 \%$ were "good" or "excellent."

Figures 1 and 2 present these results (SEP, 2013). Undoubtedly, these data explain the fact that based on the results of the OECD (2010), Mexico is in second to last place according to the percentage of students who completed their secondary education and managed to enter high school. Official ENLACE results show a tendency toward improvement in the percentage of "good" and "excellent." Nevertheless, still worrying is that more than $50 \%$ of students show the lowest levels of performance in mathematics. This situation reflects a critical situation in Mexico with regard to mathematics acquisition.

From a qualitative point of view, 3rd grade students in primary school can only solve mathematics problems with a low degree of difficulty (e.g., elementary operations, increasing sequence with an additive constant, identification of the predecessor of a number, etc.). Complex problems that require the usage of concepts and determination of numeric relations in various situations and topics are not accessible to the students. Some studies have shown that the only strategies used by children in traditional elementary school in Mexico during mathematics problem solving are counting with the fingers, personal drawings, and mental calculations (Butto \& Gómez, 2011; García, 2011). Such an empiric approach is very common and dominates the mathematics teaching system. No difference between the terms "digit" and "number" is considered in the program. Teachers use these terms without any reflection or explanation. Students have no real possibility to acquire the concepts of numbers or the decimal system.

According to Moreno (in Jarero, Aparicio, \& Sosa, 2013), official assessment in the classroom is still very rigid and directed by written examinations. Teachers use assessments in classroom as a control mechanism of behavior more than a real assessment of knowledge, so the goal of such control is always for administrative rather than pedagogical or didactic purposes. Written

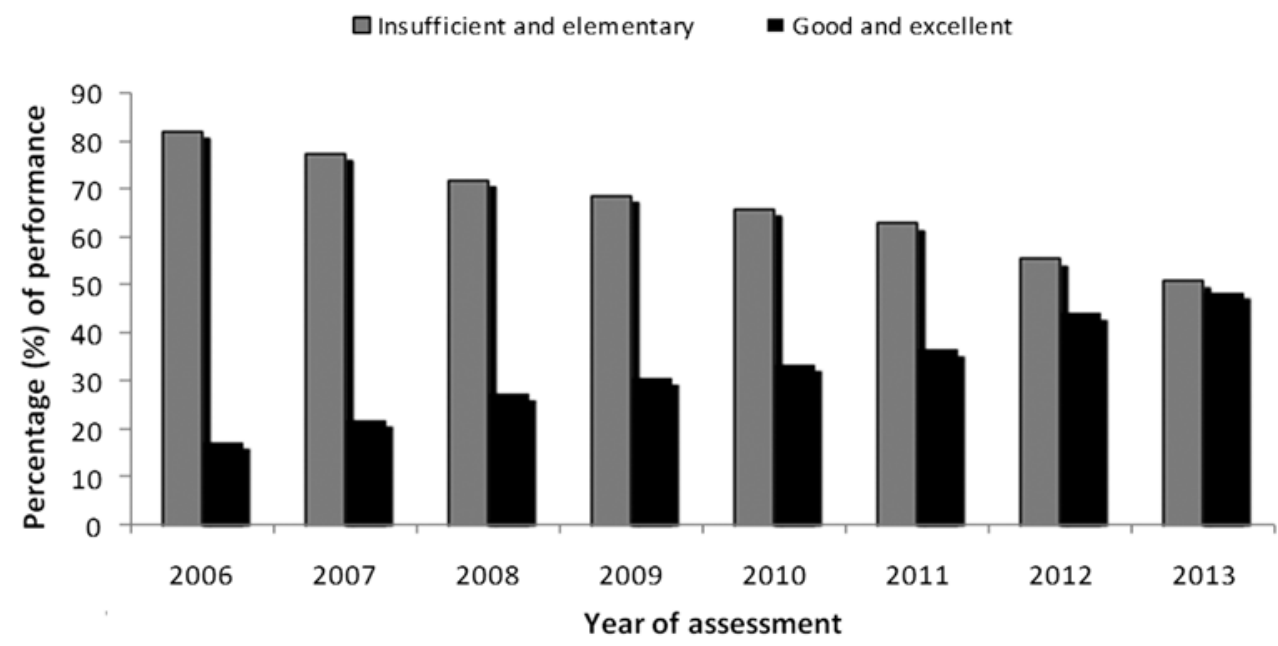

Figure 1. Historic results of performance on ENLACE test for basic education. (Modified from SEP, 2013.)

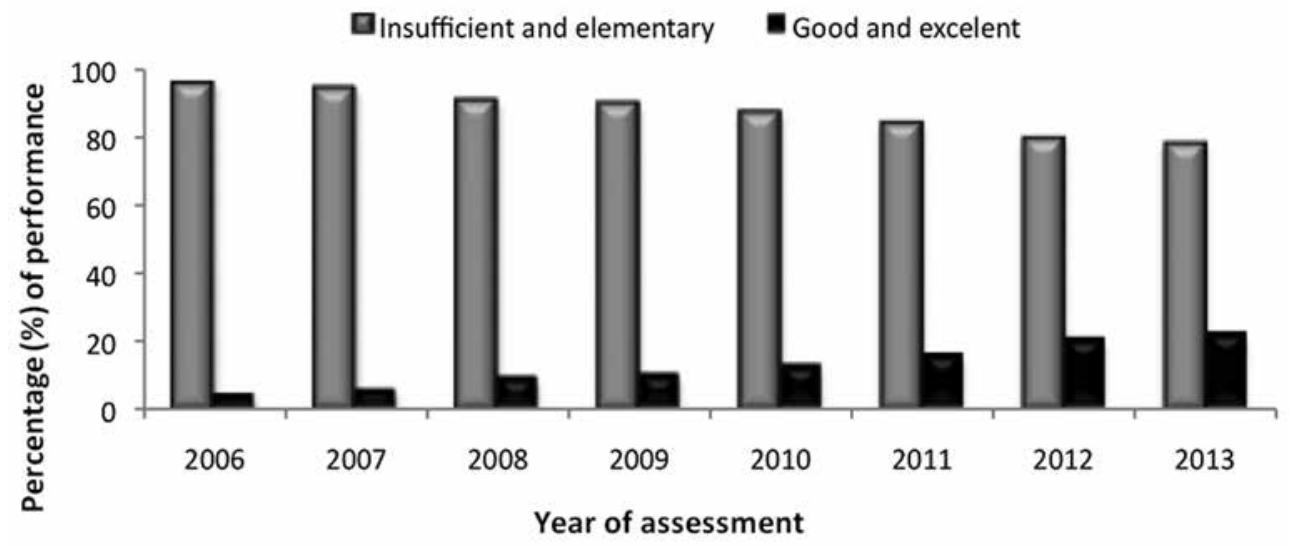

Figure 2. Historic results of performance on ENLACE test for secondary education. (Modified from SEP, 2013.) 
tests are the most common strategy used for mathematics ability assessment. Such a strategy of assessment never allows the attainment of real mathematical data or data on the strategies because only final results count.

To offer a more complete picture of the mathematics acquisition field in Mexico, we present the current situation with regard to official teaching programs, methods of assessment and correction from pedagogical and neuropsychological perspectives, and types of research related to assessment and the creation of new methods. In this article, neuropsychological approaches are considered based on cognitive, historical, and cultural paradigms that are being used by researchers in Mexico today. We believe that the inclusion of both pedagogical and neuropsychological approaches should enrich research in the field of mathematics acquisition, assessment, and correction and prevent difficulties in this area. We also stress the importance of considering proposals based on psychological activity theory, which may be a novel concept for our readers.

\section{Official programs}

In Mexico at the preschool and school educational levels, the official mathematics teaching program is based on competence (SEP, 2011a, 2011b). However, the guidelines of the program are not sufficiently clear to be used directly in the classroom. Some studies note the impossibility of constructing concrete content in such tasks or establishing strategies for presenting knowledge (Díaz \& Bermejo, 2007). The most important objective of education appears to be obtaining some kind of result so that preschool children are trained to memorize the direct counting of digits and executing arithmetic operations related to sums and remainders (Cázares, 2003). The same author claimed that preschool teachers usually constantly repeat the representation of digits in different ways (e.g., by colors, points in space, and lines), and they do not present conceptual features of the decimal system (i.e., never according to positional value). Such tasks are accompanied by the constant repetition of digit names, from 1 to 10 , so that children can actually manage to memorize, name, and draw them.

The teaching method proposed by the Public Education Secretariat for Elementary School (SEP, 2011a, 2011b) emphasizes that teachers should create learning environments to make students think about the methods to promote the communication of mathematical ideas that arise during class work and evaluate the skills that students develop. Nevertheless, no conceptual knowledge is included in the current methodology for mathematics (SEP, 2011a). Normally, children learn to sum, subtract, and execute multiple operations through constant repetition in the classroom and at home. By doing this, they do not receive any orientation or explanation about the way to "discover" the logic and theoretical basis of the decimal system or the number concept. The Education Secretariat (SEP, 2011a) emphasizes the need for reflection in primary school, which never becomes a reality. This program states that it is necessary to communicate mathematical ideas that are presented in the classroom and assess the level of ability. Nothing about how to form these abilities is mentioned.

To teach division operations, Sánchez and Llinares (2011) proposed the use of an algorithm called "little house," in which students must obtain the entire division result and remainder from the number, which can be divided into "some parts." An equation is used, and the teacher proposes short stories wherein the children must use the algorithm. The result is that the students can only perform division with whole numbers and not with fractions. This study is an example of empirical teaching based on "trial and error."

\section{Assessment of difficulties}

Frequent difficulties in mathematics acquisition have being assessed in Mexico with the aid of pedagogical tasks and also recently with neuropsychological batteries. Among the most commonly used neuropsychological cognitive tests, we can mention the Wechsler Intelligence Scale for Children (Wechsler, 2005) and Neuropsychological Assessment for Children(Evaluación Neuropsicológica Infantil or ENI in Spanish) (Rosselli et al., 2004).

Items that test mathematics abilities consist of naming digits, retaining digits, and solving arithmetic problems (Rosselli et al., 2004). Some batteries also include the copying of digits. Retention-of-digit tasks are frequently called short-term memory or working memory tasks, but their direct relation to mathematics is not entirely obvious. The most typical assessment of mathematics efficiency is based on executive function within neuropsychological tests (Anderson, 2001). The assessment of executive function is included in many neuropsychological batteries, but no specific explanation of their connections with mathematics is provided. Within a cognitive approach, assessing executive function and declaring poor success in mathematics seem to be enough (Flores, 2013).

Other methods of neuropsychological assessment include qualitative protocols that were created based on the A.R. Luria approach (Luria, 1969, 1973). Items related directly to mathematics include the copying of digits as a part of evaluating spatial analysis and synthesis (Solovieva \& Quintanar, 2013a). In this case, the conclusion is based not on any one item or a specific part of the test but rather on the general systematic characterization of the clinical picture for each child. All of the items in neuropsychological qualitative protocols are essential for the final conclusion. According to some studies, it is possible to establish that specific difficulties in mathematics learning cannot be generalized according to only one neuropsychological reason (Tsvetkova, 1972; Solovieva \& Quintanar, 2013a). Such difficulties are multifactorial and depend on functional deficits in different brain mechanisms, 
at least in regulation, control, spatial analysis, synthesis, and general brain activation. Problems with motor sequential organization could also be considered a reason for mathematics difficulties. All of these mentioned functional deficits can be detected in various combinations and do not necessarily have a pure representation. This is the reason for multiple possible combinations and individual differences in learning disabilities in mathematics and other school subjects.

Another protocol that includes tasks related to mathematics acquisition is the assessment for school preparation (Quintanar \& Solovieva, 2010). Specific items of this test are directed toward evaluating serial accommodation actions at the material and perceptual levels, mutual reciprocal object correspondence in series, and the ability to add or subtract an object or several objects to equalize the quantity. These tasks are based on previous conceptual elements regarding the number concept, such as symbolic, logical, spatial, and numerical components (Salmina \& Filimonova, 2010; Solovieva, Ortiz, \& Quintanar, 2010; Lázaro, Solovieva $\&$ Quintanar, 2013b). The presence or absence of these components in executions performed by the child shows the preparation level and can predict future difficulties with mathematics learning in school.

At school age, another protocol for neuropsychological assessment has been used (Solovieva \& Quintanar, 2012). The tasks related to mathematics consist of solving arithmetic and thematic problems. The results obtained in these tasks should always be compared with evidence of functional component difficulties in higher psychological functions, such as motor sequential organization, regulation and control, spatial analyses and synthesis, phonematic and kinesthetic integration, and general cortical activation (Quintanar \& Solovieva, 2007; Solovieva, Lázaro, \& Quintanar, 2008).

The data in the protocols applied in Mexican child populations usually show low levels of preparation for school in general (Quintanar, Solovieva, \& Lázaro, 2008) and particularly mathematics acquisition (Solovieva, Lázaro \& Quintanar, 2013).

With regard to prevention and correction, the prevention situation in Mexico is currently quite poor, and only a few experimental studies have been performed with preschool children and students in elementary school (Bonilla, Solovieva, \& Jimenez, 2012; Solovieva \& Quintanar, 2013c; Solovieva, Rosas, Quintanar, \& García, 2013). These studies were conducted based on the development of historical and cultural paradigms. Nevertheless, the commonly used general psychological paradigms in Mexico are based on Piaget's genetic theory (Piaget, 1977) that corresponds to the observational method, data recording, the prevention method, and formation (Lázaro et al., 2013). Social psychological studies have existed in Mexico for nearly 35 years, but real solutions to difficulties are rare (Ursini, 2013).

\section{Academic research}

Today in Mexico, the Mathematics Education Research Center (CINVESTAV-Instituto Politécnico) basically considers socioepistemological theory with regard to conceptual mathematics knowledge construction. The objective is to consider mathematics as a cultural product that has centuries of history and epistemological processes. Such knowledge has to be constructed on a social basis according to needs, practice, and pragmatism (Cantoral \& Farfán, 2003; Cordero \& Silva, 2012). The intention is to study four components of the construction of knowledge: epistemological nature, sociocultural dimension, cognitive plan, and teaching transmission mode. The topic of teaching was studied based on social needs. School teaching systems that influence the acquisition of such concepts were studied. Two general lines of research exist: (1) studies of the significance of knowledge and (2) studies of the usage of knowledge. The first line of research includes problems regarding significance of mathematics knowledge at school. The second line of research reflects the construction of functional knowledge and graphical forms for specific situations (Cantoral \& Farfán, 2003; Cordero \& Silva, 2012).

Other studies were focused on students' "cognitive styles," which was considered a particular form of mathematics learning and problem solution. Before beginning to teach any kind of academic content, detecting the academic styles of students is important. One cognitive type can process information, whereas another type describes how a student can be concentrated based on cognitive, affective, and physiological features. Such features may be different according to age, sex, and level of success (Toledo, Pérez, Riquelme, Hernández, \& Bittner, 2011).

García (2011) observed that students at the level of basic education have trouble understanding the positional value of digits. The children realize the addition operation without any algorithm and without any knowledge of the decimal system. The common strategies used by the students are pictures, fingers, and mental calculations.

At high educational levels and with the development of logical abilities, university students were shown to have difficulties with the creation of definitions and proposition usage, and they were unable to demonstrate their points of view. The authors claimed the necessity to study other logical abilities, use logical connectors, and use different kinds of demonstrations and historical references (Alvarado \& González, 2013).

Different studies have been interested in describing the mathematical content assimilation process (i.e., the kinds of strategies that students use) and proposed methods of intervention. The methodology of these studies has been frequently qualitative, and the usage of didactics is stressed (Contreras \& Contreras, 2011; Santos, 2011; Buenrostro, 2003).

Other mathematics teaching methods and interventions in cases of difficulty also exist. Ávila \& 
García (2008) revised the mathematics teaching methods from a "modern" point of view and proposed the arithmetic solution of problems in children in elementary school (e.g., division usage within the decimal system concept before proposing the algorithm). Such a method may be interesting but requires the formation of the concept of the decimal system, which is absent in the majority of children.

The proposal establishes the creation of a kind of "curricular contract" that is signed by teachers and students. The objective is to guarantee an interactive studying environment. The necessity of studying mathematics outside the classroom is stressed for both elementary and high school students (Espinoza, Barbé, \& Galvez, 2011).

Some methods have been proposed based on Cuissenaire's colored numbers and Bancubi's methods. The colored numbers are usually used at manipulative, graphic and symbolic stages. Children learn number decomposition and make initial calculations. In the manipulative stage, children empirically use colored numbers and progress to classification, comparison, and seriation. In the second and third stages, the children have to discover number inclusion, operations, and relations (Silva \& Varela, 2010). Bancubi's (2009) methods include colored cube series (units), wood sticks (tens), and wood blocks (thousands). This method is used to teach numbers, the decimal system, fractions, areas, and perimeters. The children follow the teacher's actions.

These methods show the manipulation of some objects in the initial stage, but only empirical manipulation is considered. The entire systematic structure of the numerical system is never presented or explained. The children never understand the operation sequences and can never solve the problems in an independent manner (Solovieva et al., 2010).

In Mexico, the predominant approach to difficulties in mathematics comprehension is always of a psychopedagogical nature, probably because the difficulties are very common and present at all levels of education. However, some authors claim that simply psychopedagogical and social reasons cannot explain all of the types of difficulties. We also have to admit that the pure neuropsychological characterization of mathematics difficulties does not seem to be appropriate. Populations with "dyscalculia" (i.e., a neuropsychological deficit) are very limited and practically do not exist in the university student population.

From a cognitive neuropsychology perspective, the main objective is to establish the participation of neuronal structures for numerical processing. The triple codification model implies that numerical information can be represented by three codes: (1) quantity representation, (2) verbal codes, and (3) visual codes. The information can be transformed from one code to another. Each code has been directly connected to specific cortical zones. This was confirmed using neurovisualization techniques (Serra, Adan, Pérez, Lachica \& Membrives, 2010). The cognitive approach tries to establish direct relations between different numerical operations, such as Arabic number recognition or digit categorization, and brain neuronal systems (Jacubovich, 2006). The importance of establishing such relations for didactic methods has been proposed, which could help the maturation of corresponding brain areas. The authors claim that traditional teaching is insufficient for the development of executive function that guarantees abstract mathematical thinking (Radford $\&$ André, 2009). Some studies in Mexico have been directed toward determining the relations between mathematics success and test success for executive function.

For example, in a neuropsychological study conducted at the Psychology Faculty, National Autonomous University of Mexico (UNAM), executive function, including planning, mental flexibility, strategy elaboration, metacognition, working memory, self-regulation, and activity control, was tested in calculation and logical mathematical reasoning tasks (Sánchez-Ruiz \& Escotto-Córdova, 2013; Sánchez, Escotto, Becerra, García, Contreras, \& Baltazar, 2012a). A nonoptimal level of development of executive function could be involved in mathematics difficulties and the domain of logic. The authors proposed to not use the term "acalculia," which is understood as a brain lesion with inadequate executive function "during school life at university" (Escotto-Córdova, Sánchez-Ruiz, Baltazar-Ramos, Contreras-Ramírez, Becerra-Castellanos, \& García-Pérez, 2013). A neuropsychological study based on executive function assessment with the Battery for Frontal and Executive Functions was conducted in 149 university students (Flores, Ostrosky-Solís, \& Lozano, 2008), showing the absence of significant differences between students with low and high levels of performance in the area of statistics. No significant differences were found in working memory (Sánchez, Escotto, Becerra, García, Contreras \& Baltazar, 2012b). In all of the groups studied, executive function was normal. Nevertheless, the analysis of individual results detected subjects with low working memory performance, impulse control, and planning, but no relation was found with mathematics level. Such studies suggest that university students with mathematics difficulties do not have problems in executive function but may be at a non-optimal level. Such subjects may have a history of diverse neuropsychological deficits, dyslexia, or attention-deficit hyperactivity disorder.

The analysis of formal logical reasoning using the Logic Reasoning Test (Acevedo \& Oliva, 1995) revealed important correlations between low mathematics success and formal logical reasoning. We can conclude that specific pedagogical preparation at medium to high levels of education should include formal logic, a situation that is presently not occurring in Mexico. 


\section{Correction and prevention}

Correction can be understood from the pedagogical and neuropsychological perspectives. Traditional pedagogical correction is based on constant repetition and training of the same tasks that are used in the classroom. There are no effective alternatives, or they appear only in the experimental context (Buenrostro, 2013). Neuropsychologists appear to be more active in offering proposals in the area of correction. Cognitive proposals are directed toward meta-cognition, executive function, and their different components. The effect of such interventions is not specific for mathematics and has not resonated within society. Neuropsychological interventions are usually provided for children with learning disabilities and not for regular children. Not only children with learning disabilities require correction strategies; elementary school students in Mexico also need them. From this point of view, the proposals made by cognitive neuropsychologists do not appear to be specific to mathematics difficulties.

The prevention of mathematics difficulties in the normal general population could be specifically organized from an Activity Theory perspective and using a cultural historical approach. This means that it is necessary to correctly orient children in numerical and mathematical concepts. Such orientation cannot be considered "metacognition" or the training of "executive functions" but should include actions by adults to help based on the proximate development zone concept (Vigotsky, 1991; Talizina, 2009). It is well known that this is a particular way of thinking that is not shared by all psychologists or neuropsychologists. Moreover, it has been rejected by the majority of cognitive psychologists. Nonetheless, acquainting oneself with this theory and its possibilities appears to be useful.

In traditional teaching, these components are not considered important knowledge or aspects of learning. Symbolic preparation is not even mentioned as a term related to mathematics. The symbols are presented to children just as material objects, with no differentiation between object usage and symbols. The current curricular methods are based on traditional repetition and memorization without symbolic or logical concepts of numerical structure or the decimal system.

In teaching in school, the concepts are not introduced in concrete didactics that are directed toward the execution of operations and memorization of tables and formulas. Problem solving is rare in classrooms.

Nevertheless, the number concept and decimal system represent essential aspects of difficulties in elementary school. This is the subject that apparently comprises most of the activities in the first 3 years of elementary school education (Ruesga \& Guimaraes, 2011). The decimal system should be considered a positional system because the digits are not independent and subject to spatial position. No digit has absolute meaning; it depends on its specific spatial position (Ávila \& García, 2008; Silva \& Barela, 2010; Tsvetkova, 1972).
The problem is that such knowledge is not explicit, and apparently children have to "discover" it.

We may agree that pedagogical tradition has no response to the situation of difficulties in mathematics learning. But this does not mean that non-traditional methods cannot teach processes and didactics based on pedagogical psychology (Talizina, 2000, 2001, 2009; Talizina, Solovieva, \& Quintanar, 2010). An answer may be found for non-traditional education based on Activity Theory (Talizina et al., 2010; Solovieva \& Quintanar; 2010; Galperin, 2009; Talizina, 2009; Salmina, 2001). This general psychological theory, applied to teaching and the learning process, shows how it is possible to reorganize and systematize academic programs to guarantee favorable assimilation and the generalization of knowledge. Among the main aspects of such a methodology, we can highlight (1) constant orientation in the formation of theoretical concepts and (2) symbolic external representation of phenomena or processes that should be learned.

At the initial level of introducing mathematics, mathematical content should be organized around four components-logical, symbolic, mathematical, and spatial - that have been discussed in previous psychological studies based on Activity Theory (Salmina \& Filimonova, 2010; Solovieva et al., 2010; Solovieva, Quintanar \& Ortiz, 2012). The decimal system is undoubtedly a symbolic system that is based on the relative meaning of each digit (Salmina, 2001). No digit has a direct meaning - it changes according to its spatial position. However, only direct meaning and direct correspondence to the quantity is taught in school. Positions left or right of the decimal point also have specific meanings in the decimal system. In this case, spatial orientation is essential and a reason why it should be included as a component in the introduction of the concept in mathematics (Solovieva et al., 2010).

In primary school, introduction of the number concept and decimal system can be organized and guided by a teacher. Such organization can guarantee reflective and conscious acquisition of the proposed concepts. Specific kinds of external symbolic representations can be used during the teaching process. The teacher always presents both orientation and symbolic means for solving problems, and the student can propose the materials for each of the actions. An example of such a representation of orientation for number concept formation within the measurement action is shown in Box 1.

Magnitude $(\mathrm{M})=$ object or parameter that we want to measure (What do we want to measure?)

Measurement $(\mathrm{m})=$ symbol or means that we choose as a measure (What do we measure with?)

Quantity of time (v) = Number of times we use the measure (How many times do we measure by this means?)

Box 1. Symbolic card for measurement orientation. 
In the case of forming the decimal system concept, another external model for representation may be used. Children can measure units of action in such a way that each subsequent unit of measure can be 10-times larger than the previous one. That unit is called a "ten." Figure 3 shows an elaboration of a symbolic external scheme for the representation of grades within the decimal system (Solovieva et al., 2013). When the student counts and gets 10 or more units, he can "pass" to the next unit on the right side of the scheme.

Figure 4 shows how the student can organize the decimal system model in a materialized form as the result of constant conceptual orientation and the fulfillment of joint actions between the student and teacher.

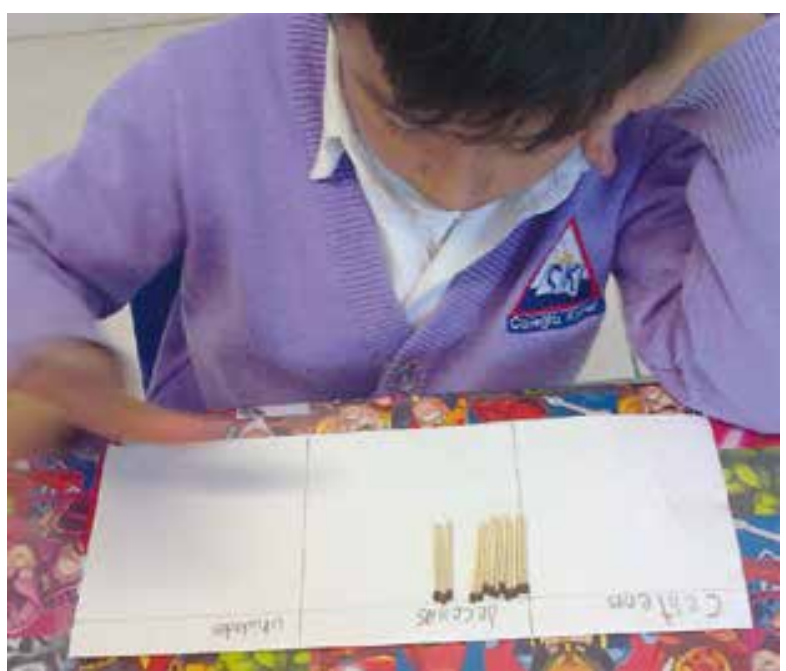

Figure 3. Representation of units and tens with external scheme.



Figure 4. Tens construction and numerical representation.
For such a method, children can learn to represent different numbers and different quantities using symbolic schemes for the decimal system. In all of the tasks, children have to identify the largest and smallest units and differentiate the "digit" and "positional unit" concepts.

The non-traditional mathematical assessment of conceptual ability according to Activity Theory can be realized by asking conceptual questions instead of providing examples of solutions and operations. Table 1 presents some examples of empirical and conceptual answers given by children.

It is possible to notice the qualitative difference between the empirical level perception and logical theoretical comprehension of mathematic relations. It is possible to propose specific methods to form logical theoretical comprehension instead of chaotic empirical perception. We consider that this is possible because our experimental data at the preschool and school levels in Mexico have always demonstrated such a possibility and methodological success (Zárraga, Quintanar, Garcia, \& Solovieva, 2012; Rosas, Solovieva, García, \& Quintanar, 2013; Rosas, 2013).

Such a way of teaching has to be opposite to the constructivist working methods that simply separate individual child actions with no specific established purpose and stress the teaching of symbols just as any other external object that is presented to the child (Martin, 2003; Castaño, 2008). The techniques used in the constructivist approach are never properly applied to the measurement action. Those methods purport to measure only empirically without any objective and no relation to the decimal system concept.

The mathematics teaching process in school should be understood as a directed and organized process (Talizina et al., 2010) and not the empirical selection of several operations and actions. The teacher should clearly understand what she is teaching and how the best result can be achieved. Such a teaching organization process allows children to be conscious of their learning (Talizina, 2009) and allows and guarantees the development of mathematical skills in children. Only the right choice and organization of appropriate actions may drive positive teaching results. Such actions are related to object feature measurements (e.g., highness, broadness, and volume).

Constant orientation using symbolic means helps answer specific questions with constant adult participation,

Table 1. Empirical and theoretical answers to conceptual questions

\begin{tabular}{|c|c|c|}
\hline Task & Empirical answers & Conceptual answers \\
\hline Which one is the biggest: $3 \mathrm{~cm}$ or $1 \mathrm{~m}$ ? & 3 , because 3 is bigger than one. & $\begin{array}{l}1 \text { meter is bigger than } 3 \text { centimeters because } \\
1 \text { meter includes } 100 \text { centimeters. }\end{array}$ \\
\hline $\begin{array}{l}\text { Which one is the biggest: } 5 \text { liters or } 2 \\
\text { kilograms? }\end{array}$ & 5 is bigger than 2 . & $\begin{array}{l}\text { It is not possible to answer; different means } \\
\text { were used for the measurements. }\end{array}$ \\
\hline $\begin{array}{l}\text { Which is the biggest: two quarters of an hour } \\
\text { or a half hour? }\end{array}$ & $\begin{array}{l}\text { I don't know, I haven't been taught to read } \\
\text { the clock. }\end{array}$ & $\begin{array}{l}\text { They are equal because one quarter plus one } \\
\text { quarter equals a half hour. }\end{array}$ \\
\hline
\end{tabular}


which are essential parts of our methodology. Only this kind of organization in the learning process can guarantee successful assimilation and generalization of the decimal system concept (Davidov, 1988; Salmina, 2010). The purpose of each activity and each task is explained and oriented by the teacher. After such training, we found no mistakes in the reading of new numbers presented to the children. Such mistakes have been found by some researchers in Mexico and other countries as a constant negative feature of children in elementary school (Butto \& Gómez, 2011; García, 2011; Gómez, 1991).

The principles of innovative teaching according to Activity Theory methodology can provide new insights into the educational process. By including these concepts, it is possible to create original strategies that ensure an understanding of initial mathematical concepts and problem solving.

\section{Final considerations and proposals}

The existing tests for mathematics assessment can be divided into two groups: (1) psychological and pedagogical procedures and (2) neuropsychological tests. Both of these can be subdivided according to the paradigm used (consciously and unconsciously by specialists): cognitive and cultural historical. Psychological and pedagogical procedures from the cognitive perspective propose the direct evaluation of operation solutions as an isolated cognitive process. The conclusion made after these tests are employed can only show whether the students can or cannot complete a specific task. No structural dependence or reasons for difficulties can be determined.

The proposed procedures from the cultural historical perspective related to psychological development (after Vigotsky, 1995) and Activity Theory (after Leontiev, 2009) represent an alternative assessment and way of teaching. Instead of providing direct examples of arithmetic solutions or problems, conceptual questions (Table 1) can be proposed. For the very beginning of elementary school, we propose the evaluation of components of systematic concept formation in mathematics, including symbolic actions, spatial orientation at different levels, logic, and numerical actions. Such assessment will detect what students can and cannot do, help discover possible reasons for their difficulties, help critically evaluate current methods, and allow proposals of innovative and creative teaching procedures and learning processes.

In the case of neuropsychological assessment from the cognitive perspective, specialists evaluate different cognitive functions or processes in isolation. Normally, they relate mathematics acquisition difficulties only with insufficiency in so-called executive function. In such a case, it does not matter if the child shows or does not show difficulties in other subject areas in school (e.g., reading or writing). It seems to be sufficient to simply determine that problems exist in executive function. The direct conclusion is insufficient frontal lobe function or smaller orbital frontal lobe size (Flores, 2013). Normally, no neurophysiological or electrophysiological confirmation of such conclusions is made in cognitive studies. We believe that this reasoning is not effective in cases of mathematics acquisition difficulties. Executive function can be presumed to be necessary for all cognitive activities, and it is quite difficult to draw conclusions about specific (conceptual) relations about what they "do" precisely in mathematics.

In cases of neuropsychological assessment from the cultural historical perspective, the neuropsychologist would never assess mathematics separately. The functional effect of systemic weakness of any components of higher psychological functions would always be reflected in difficulties in different types of cognitive tasks. Syndrome analysis based on the Luria's school of neuropsychology seeks to determine functional components of school actions (Solovieva \& Quintanar, 2007). From this point of view, the syndrome is never interpreted as "dyscalculia" in isolation from other cognitive processes. The weakness of one functional brain mechanism or factor can produce difficulties in different school activities and never just in one kind of activity. According to research in this field, mathematics acquisition difficulties can be caused by several functional deficits and not only by an insufficiency in executive function. Such functional deficits in the case of mathematics can be related to weaknesses in regulation and control, spatial analysis and synthesis, and general cortical activation. Such weakness produces systemic effects in different types of cognitive tasks that cannot be fully rectified by the child. Therefore, difficulties in mathematics are not considered isolated difficulties by neuropsychologists. Neuropsychological syndrome analysis can help understand brain function with regard to mathematical thinking problems and relate them to difficulties in other cognitive domains. If the student only has difficulties in mathematics and if no neuropsychological syndrome can be detected, then the conclusion is that it is a pedagogical and conceptual problem and not of neuropsychological origin.

As we mentioned above, both perspectives are represented in Mexico and have a considerable number of followers. Teaching strategies and methods of correcting difficulties are directly related to these same two paradigms.

In the case of pedagogical and psychological assessment from the cognitive perspective, arithmetic operations can be directly trained. In additional sessions after school, students are trained in repeating and memorizing multiplication and division operations and tables. No other techniques have been found.

In the case of pedagogical and psychological assessment from the Activity Theory perspective, previous elements of mathematics acquisition are usually provided through gradual formation, from the material and materialized level to the perceptual and schematic level to the verbal and conceptual level. Specific studies were performed in this area with 
positive and effective results. During the educational school stage, specific programs were created for the reflective orientation organization of essential relations between elements of mathematical situations. These programs included methods for the gradual formation of the number concept (Solovieva et al., 2010), decimal system concept (Talizina, 2001, 2009; Rosas et al., 2013), and multiplication and division operations (Rosas, 2013). We believe that the creative continuation of this area may be the only effective solution for the complex situation with mathematics learning in school.

In the case of neuropsychological correction from the cognitive perspective, the most common approach is addressing executive function separately as the only possible reason for mathematics acquisition difficulties. Such interventions are never specific for mathematics and are instead general and global and cannot be considered an essential element of the problem.

In the case of neuropsychological correction from the cultural historical perspective, the goal of correction is never related to mathematics itself but rather the gradual development of weak components of higher psychological functions. We can state again that important components for mathematics include regulation and control, spatial analysis and synthesis, and general cortical activation. Correction programs from a neuropsychological perspective include joint tasks, in which the child is involved with a therapist. After the implementation of such correction programs, improvements in all cognitive areas can be observed, never just in mathematics (Quintanar, Lázaro, \& Solovieva, 2009; Solovieva \& Quintanar, 2013c). Both neuropsychological approaches are common in Mexico, and it is practically impossible to find any neuropsychologist with a "third," alterative approach.

It is necessary to consider two specific reasons for mathematics acquisition: pedagogical and neuropsychological. Both should be considered, but authors frequently consider them separately. In the case of pedagogical difficulties, only problems with mathematics acquisition are considered, with no consideration of other school subjects. In addition to mathematics difficulties and low school marks, it is necessary to establish the absence of conceptual reasoning and rote and chaotic answers by the students.

In the case of neuropsychological reasons, we found systemic difficulties with other cognitive tasks and never just in mathematics. This may be explained from the cultural historical perspective. In cognitive science, such parameters are frequently confused and combined together (we mean the consideration of difficulties only in mathematics and not in other school areas in the same child). This occurs because of the evaluation of executive function or mathematical operations without considering other actions or processes. It is quite frequent to find both pedagogical and neuropsychological reasons in an elementary school student. The same student can have substantial difficulties because of the absence of essential school preparation because of psychological reasons and because of functional deficits (e.g., in spatial synthesis). Special correction programs have to be developed to include both the pedagogical and neuropsychological points of view.

We believe that searching for only one reason for mathematics difficulties based on only a pedagogical, psychological, or neuropsychological approach will not help our understanding of the nature of the problem. Only constructive, analytic, and synthetic combinations of different approaches will be useful in the future.

\section{References}

Acevedo, A., \& Oliva, J. (1995). Validación y aplicaciones de un test de razonamiento lógico. Revista de Psicología General y Aplicada, 48(3), 339-351.

Alvarado, A., \& González, M. T. (2013). Generación interactiva del conocimiento para iniciarse en el manejo de implicaciones lógicas. RELIME, 16(1), 37-63.

Anderson, V. (2001). Assessing executive functions in children: biological, psychological, and developmental considerations. Pediatric Rehabilitation, 4(3), 119-136.

Ávila, A. \& García, S. (2008). Los decimales: más que una escritura. México Distrito Federal: INEE.

Bancubi (2009). Método Bancubi. Retrieved from: http://www. bancubi.com/bancubi.htm; accessed August 14, 2014.

Block, D., \& Solares, D. (2001). Las fracciones y la división en la escuela primaria: análisis didáctico de un vínculo. Educación Matemática, 13(2), 5-30.

Bonilla, M., Solovieva, Y., \& Jiménez N. (2012). Valoración del nivel de desarrollo simbólico en la edad preescolar. Revista CES Psicología, 5(2), 56-69.

Buenrostro, A. V. (2003). Aritmética y bajo rendimiento escolar. Tesis de doctorado en ciencias en la especialidad de matemática educativa. México Distrito Federal: Centro de Investigación y Estudios Avanzados del IPN.

Buenrostro, A. V. (2013). Dificultades en el aprendizaje de las matemáticas en los primeros grados escolares. In: J. Sánchez, \& A. Escotto (Eds.), Dificultades en el aprendizaje de las matemáticas. factores neuropsicológicos, afectivos y socioepistemológicos (pp. 73-86). México Distrito Federal: UNAM.

Butto, C., \& Gómez, L. M. (2011). Las representaciones del sistema numérico decimal indo-arábigo en niños de primer grado de primaria. XIX Congreso Mexicano de Psicología. Cancún: Cancún Center, Quintana Roo, México.

Cantoral, R., \& Farfán, R. M. (2003). Matemática educativa: una visión de su evolución. RELIME, 6(1), 27-40.

Castaño, J. (2008). Una aproximación al proceso de comprensión de los numerales por parte de los niños: relaciones entre representaciones mentales y semióticas. Universitas Psichological, 7(3), 895-907.

Cazares, J. (2003). La enseñanza y el aprendizaje de la aritmética en tercero de preescolar. México Distrito Federal: SEP CONACYT.

Contreras, S., \& Contreras, A. (2011). Estilos de aprendizaje del profesor y sus estilos de enseñanza. XIX Congreso Mexicano de Psicología. Cancún: Cancún Center, Quintana Roo, México.

Cordeo, F., \& Silva, H. (2012). Matemática educativa, identidad y Latinoamerica: quehacer y la usanza del conocimiento disciplinar. RELIME, 15(3), 295-318.

Davidov, V. (1988). La enseñanza escolar y el desarrollo psíquico. Moscú: Progreso.

Díaz, J. \& Bermejo, V. (2007). Nivel de abstracción de los problemas aritméticos en niños urbanos y rurales. Revista Latinoamericana de Investigación en Matemática Educativa, 10 (3), 335-364.

Escotto Córdova, E. A., Sánchez-Ruiz, J. G., Baltazar-Ramos, A., Contreras-Ramírez, M. S., Becerra-Castellanos, J., \& GarcíaPérez, J. M. (2013). Acalculia. In: J. G. Sánchez, \& A. Escotto (Eds.), Dificultades en el aprendizaje de las matemáticas: factores neuropsicológicos afectivos y socioepistemológicos (pp. 41-56). México Distrito Federal: UNAM.

Espinoza, L., Barbé, J., \& Galvéz, G. (2011). Limitaciones en el desarrollo de la actividad matemática en la escuela básica: el caso de la aritmética escolar. Estudios Pedagógicos, 37(1), 105-125.

Flores, J. C. (2013). Las funciones ejecutivas en el aprendizaje. In: J. Sánchez, \& A. Escotto (Eds.), Dificultades en el aprendizaje 
de las matemáticas: factores neuropsicológicos, afectivos y socioepistemológicos (pp. 27-40). México Distrito Federal: UNAM.

Flores, J. C., Ostrosky-Solís, F., \& Lozano, A. (2008). Batería de funciones frontales y ejecutivas: presentación. Revista Neuropsicología, Neuropsiquiatría y Neurociencias, 8(1), 141158.

Galperin, P. Y. (2009). La formación de los conceptos y de las acciones mentales. In: L. Quintanar, \& Y. Solovieva (Eds.), Las funciones psicológicas en el desarrollo del niño. México Distrito Federal: Trillas.

García, O. (2011). Las matemáticas naturales del niño y su transición a la educación formal en la escuela formal. XIX Congreso Mexicano de Psicología. Cancún: Cancún Center, Quintana Roo, México.

Gómez, C. (1991). Cognición, contexto y enseñanza de las matemáticas. Comunicación, Lenguaje y Educación, 11, 11-26.

Jacubovich, S. (2006). Modelos actuales de procesamiento del número y el cálculo. Revista Argentina de Neuropsicología, 7, 21-31.

Jarero, M., Aparicio, E., \& Sosa, L. (2013). Pruebas escritas como estrategias de evaluación de aprendizajes matemáticos: un estudio de caso a nivel superior. RELIME, 16(2), 213-243.

Lázaro, E., Solovieva, Y., \& Quintanar, L. (2013). Premisas psicológicas para la adquisición del cálculo. In: J. Sánchez, \& A. Escotto (Eds.), Dificultades en el aprendizaje de las matemáticas: factores neuropsicológicos, afectivos y socioepistemológicos (pp. 57-71). México Distrito Federal: UNAM.

Leontiev, A. N. (2009). Bases psicológicas del desarrollo del niño y de La enseñanza. Moscú: Sentido.

Luria, A. R. (1969). Las funciones corticales superiores del hombre. Moscú: Universidad Estatal de Moscú.

Luria, A. R. (1973). Introducción a la neuropsicología. Moscú: Universidad Estatal de Moscú.

Martín, A. (2003). Operación aritmética: la división. Boletín: Las Matemáticas en Secundaria, 25.

OCDE (2010). Panorama de la educación 2010: indicadores de la $O C D E$. Madrid: Santillana.

Piaget, J. (1977). L'épistémologie génétique. In: J. Piaget, \& R. Evans. Mes idées (pp. 37-54). Paris: Denoel-Gonthier.

Quintanar, L., \& Solovieva, Y. (2010). Evaluación neuropsicológica de la actividad del niño preescolar. Puebla: Universidad Autónoma de Puebla.

Quintanar, L., \& Solovieva, Y. (2007). Neuropsicología y aprendizaje escolar. Ciencia y Desarrollo, 33(212), 61-65.

Quintanar, L., Lázaro, E., \& Solovieva, Y. (2009). La rehabilitación neuropsicológica a través de la reorganización de los sistemas funcionales. In: A. Escotto, M. Pérez, \& M.A. Villa (Eds.), Desarrollo y alteraciones del lenguaje, neuropsicología y genética de la inteligencia (pp. 249-273). México Distrito Federal: UNAM.

Quintanar, L., Solovieva, Y., \& Lázaro, E. (2008). Evaluación neuropsicológica infantil breve para la población hispano-parlante. Acta Neurológica Colombiana, 24, 31-44.

Radford, L., \& André, M. (2009). Cerebro, cognición y matemáticas. RELIME, 12(2), 215-250.

Rosas, Y. (2013). Formación de la acción de división en niños de segundo grado de primaria. Tesis de grado. Puebla: Universidad Autónoma de Puebla.

Rosas, Y., Solovieva, Y., García, M., \& Quintanar, L. (2013). Formation of concept of decimal system in Mexican school children. Clinical and Special Psychology, 1, 18-38.

Rosselli, M., Matute, E., Ardila, A., Botero, V.E., Tangarife, G.A., Echeverría, S.E., Arbelaez, C., Mejía, M., Méndez, L.C., Villa, P.C., \& Ocampo, P. (2004). Evaluación Neuropsicológica Infantil (ENI): una batería para la evaluación de niños entre 5 y 16 años de edad: estudio normativo colombiano. Revista de Neurología, 38(8), 720-731.

Ruesga, P., \& Guimaraes, G. (2011). Sistema de numeración decimal: un instrumento para seleccionar los libros de texto de los tres primeros años de enseñanza. XIII CIAEM-IACME, Brasil, 13 , 1-12. Retrieved from: http://www.cimm.ucr.ac.cr/ocs/index.php/ xiii_ciaem/xiii_ciaem/paper/viewFile/399/1215; accessed August 14,2014

Salmina, N. (2001). La enseñanza de las matemáticas en la escuela primaria. In N. Talizina (Ed.), La formación de las habilidades del pensamiento matemático (pp. 40-86). San Luis Potosí: Universidad Autónoma de San Luis Potosí.

Salmina, N., \& Filiminova, O. (2010). Problemas en el aprendizaje de las matemáticas básicas y su corrección. Puebla: Instituto Universitario de Estudios Avanzados.
Sánchez, E., \& Llinares, S. (2011). Didáctica de las matemáticas y el profesor de los niveles básicos. In: SEP (Ed.). Aprendizaje y enseñanza de las matemáticas escolares: casos y perspectivas. México Distrito Federal: SEP.

Sánchez, J.G., \& Escotto-Córdova, E.A. (2013). Dificultades en el aprendizaje de las matemáticas: factores neuropsicológicos afectivos y socioepistemológicos. México Distrito Federal: UNAM.

Sánchez, J., Escotto, A., Becerra, J., García, J., Contreras, M., \& Baltazar, R.A. (2012a). Dificultades en el aprendizaje de las matemáticas y memoria de trabajo. Revista Mexicana de Psicología, October, 2235-2239.

Sánchez, R.J., Escotto, C.A., Becerra, J., García, J.M., Contreras, M.S., \& Baltazar, A.M. (2012b). Correlatos neuropsicológicos del bajo rendimiento en matemática en estudiantes de la carrera de psicología: el papel de las funciones ejecutivas. Acta Latinoamericana de Matemática Educativa, 25, 55-63.

Santos, D. (2011). Micro-mundo, aprendizaje autoregulado y estatus epistemológico de información subjetiva matemática. XIX Congreso Mexicano de Psicología. Cancún: Cancún Center, Quintana Roo, México.

SEP (2011a). Programa de Estudio 2011. Guía para el maestro. Educación Básica Primaria, primer grado. México Distrito Federal: Secretaría de Educación Pública.

SEP (2011b). Programas de estudio 2011. Guía para el maestro. Educación básica de tercer grado de primaria. México Distrito Federal: Secretaría de Educación Pública.

SEP (2013). Resultados históricos nacionales 2006-2013. México Distrito Federal: Secretaría de Educación Pública. Retrieved from: http://www.enlace.sep.gob.mx/content/gr/docs/2013/historico/00 EB 2013; accessed August 14, 2014

Serra, A., Adán, A., Pérez, L., Lachica, J. \& Membrives, S. (2010). Bases neurales del procesamiento numérico y del cálculo. Revista de Neurología, 50(1), 39-46.

Silva, A., \& Barela, C. (2010). Los materiales concretos en la enseñanza de la numeración. Quehacer Educativo, June, 26-33.

Solovieva, Y., Quintanar, L., \& Ortiz, G. (2012). The formation of initial components of number concepts in Mexican children. Psychology Research, 2(7), 422-430.

Solovieva, Y., Lázaro, E., \& Quintanar, L. (2008). Aproximación histórico-cultural: evaluación de los trastornos del aprendizaje. In: J. Eslava, L. Mejía, L. Quintanar, \& Y. Solovieva (Eds.), Los trastornos de aprendizaje: perspectivas neuropsicológicas (pp. 182-226). Bogotá: Magisterio.

Solovieva, Y, Ortiz, G., \& Quintanar, L. (2010). Formación de conceptos numéricos iniciales en una población de niños mexicanos. Cultura y Educación, 20(3), 345-361.

Solovieva, Y., \& Quintanar, L. (2010). El desarrollo del niño y los métodos de enseñanza. Elementos, 77, 9-13.

Solovieva, Y., Rosas, Y., Quintanar, L., \& García, M.A. (2013). Symbolic representation for introduction of decimal system in Mexican school children. International Education Studies, 6(10), $102-111$

Solovieva, Y., \& Quintanar, L. (2007). Análisis neuropsicológico de la acción escolar. Revista General de Psicología Aplicada, 60, 217-234.

Solovieva, Y., \& Quintanar, L. (2012). Evaluación neuropsicológica de la actividad escolar. Puebla: Universidad Autónoma de Puebla.

Solovieva, Y., \& Quintanar, L. (2013a). Evaluación del desarrollo simbólico en niños preescolares Mexicanos. Cultura y Educación, 25(2), 167-182.

Solovieva, Y., \& Quintanar, L. (2013b). Educación neuropsicológica infantil. Puebla: Trillas.

Solovieva, Y., \& Quintanar, L. (2013c). Evaluación neuropsicológica infantil breve. Puebla: Universidad Autónoma de Puebla.

Solovieva, Y., Lázaro, E., \& Quintanar, L. (2013). Evaluación de las habilidades matemáticas en niños preescolares urbanos y rurales. Cultura y Educación, 25(2), 199-212.

Solovieva, Y., Quintanar, L., \& Ortíz, G. (2012). The formation of initial components of number concepts in Mexican children. Psychology Research, 2(7), 422-430.

Talizina, N. (2000). Manual de Psicología Pedagógica. San Luis Potosí: Universidad Autónoma de San Luis Potosí.

Talizina, N. (2001). La formación de las habilidades matemáticas en niños escolares. San Luis Potosí: Universidad Autónoma de San Luis Potosí.

Talizina, N. (2009). La teoría de la actividad aplicada a la enseñanza. Puebla: Universidad Autónoma de Puebla. 
Talizina, N., Solovieva, Y., \& Quintanar, L. (2010). La aproximación de la actividad en psicología y su relación con el enfoque históricocultural de L. S. Vygotsky. Novedades Educativas, 230, 4-8.

Toledo, H., Pérez, E., Riquelme, V., Hernández, Z., \& Bittner, V. (2011). Evaluación de los intereses y estilos cognitivos de aprendizaje en ciencia en alumnos de $7^{\circ}$ y $8^{\circ}$ año de enseñanza básica y $1^{\circ}$ y $2^{\circ}$ de educación media de la provincia Llanquihue. Journal for Educator, Teachers and Trainers, 2, 39-48.

Tsvetkova, L.S. (1972). Alteraciones y rehabilitación del cálculo en casos de lesiones locales cerebrales. Moscú: Universidad Estatal de Moscú.

Ursini, S. (2013). Una mirada a factores psicológicos y sociales que intervienen en el aprendizaje de las matemáticas. In: J. Sánchez Ruiz, \& A. Escotto Córdova (Eds.), Dificultades en el aprendizaje de las matemáticas: factores neuropsicológicos, afectivos y socioepistemológicos (pp. 89-100). México Distrito Federal: UNAM.

Vigotsky, L.S. (1991). El problema de la enseñanza y del desarrollo intelectual en la edad escolar. In: L.S. Vigotsky. Psicología pedagógica: obras escogidas. Tomo 1 (pp. 374-390). Moscú: Pedagogía.

Vigotsky, L.S. (1995). Problemas del desarrollo de la psique. Obras Escogidas. Tomo III. Madrid: Visor.

Wechsler, D. (2005). WISC IV: Escala de Inteligencia Wechsler para Niños $I V$. Madrid: TEA.

Zárraga, S., Quintanar, L., García, M., \& Solovieva, Y. (2012). Formación de las habilidades matemáticas básicas en preescolares mayores de una comunidad suburbana. Revista Educacao e Filosofia, 26, 157-178. 